\title{
Pengaruh Manajemen Hubungan Masyarakat Terhadap Kualitas Pelayanan Akademik SMAN Darussholah Singojuruh Banyuwangi
}

\author{
Siti Aimah ${ }^{1}$, Ulfa Dwi Yanti ${ }^{2}$ \\ e-mail: sitiaimah1@iaida.ac.id ${ }^{1}$, ulfa.d918@gmail.com ${ }^{2}$ \\ Prodi Manajemen Pendidikan Islam \\ Institut Agama Islam Darussalam Blokagung Banyuwangi
}

\begin{abstract}
The purpose of this study was to find out how the application of public relations management at Darussholah Singojuruh Banyuwangi Senior High School of State. Second, how is the quality of academic services at Darussholah Singojuruh Banyuwangi Senior High School of State. Third, is there any influence of public relations management on the quality of academic services at Darussholah Singojuruh Banyuwangi Senior High School of State. Fourth, how much influence does public relations management have on the quality of academic services at Darussholah Singojuruh Banyuwangi Senior High School of State. The data collection methods used in this study are questionnaire, observation, documentation. As for the data validity test using the product moment formula, to look for data reliability using the Cornbach, Alpha formula. Then for hypothesis testing using the $T$ test and $F$ test, for the normality test using the Kolmogorov-Smirnov formula. In the analysis of data using Simple Linear Regression analysis. The results of this study indicate there is an influence of public relations management on the academic service quality of Darussholah Singojuruh Banyuwangi Senior High School of State by $74.4 \%$ while the remaining $25.6 \%$ is influenced by other variables not examined, which means the effect of public relations management on the academic quality of Darussholah Singojuruh Banyuwangi Senior High School of State is good.
\end{abstract}

Keywords: Public Relations Management, Academic Service Quality

\begin{abstract}
Abstrak
Tujuan penelitian ini adalah untuk mengetahui bagaimana penerapan manajemen hubungan masyarakat SMAN Darussholah Singojuruh. Kedua, bagaimana kualitas pelayanan akademik SMAN Darussholah Singojuruh Banyuwangi. Ketiga, adakah pengaruh manajemen hubungan masyarakat terhadap kualitas pelayanan akademik SMAN Darussholah Singojuruh Banyuwangi. Keempat, seberapa besar pengaruh manajemen hubungan masyarakat terhadap kualitas pelayanan akademik SMAN Darussholah Singojuruh Banyuwangi. Adapun metode pengumpulan data yang digunakan dalam penelitian ini ialah angket, observasi, dokumentasi. Sedangkan untuk uji validitas data menggunakan rumus product moment, untuk mencari reliabilitas data menggunakan rumus Cornbach, Alpha. Kemudian untuk pengujian hipotesis menggunakan uji $T$ dan uji $F$, untuk uji normalitas menggunakan rumus KolmogorovSmirnov. Pada analisis data menggunakan analisis Regresi Linier Sederhana. Hasil penelitian ini menunjukkan bahwa terdapat pengaruh yang manajemen hubungan masyarakat terhadap kualitas pelayanan akademik SMAN Darussholah Singojuruh sebesar 74,4\% sedangkan sisanya 25,6\% dipengaruhi oleh variabel lain yang tidak diteliti, yang berarti pengaruh manajemen hubungan masyarakat terhadap kualitas pelayanan akademik SMAN Darussholah Singojuruh adalah tergolong baik..
\end{abstract}

Kata kunci: Manajemen Hubungan Masyarakat, Kualitas Pelayanan Akademik 


\section{A. Pendahuluan}

1. Latar Belakang

Peran lembaga pendidikan di era globalisasi saat ini semakin dituntut untuk memberikan manajemen dan layanan yang professional kepada masyarakat. Hal ini dikarenakan semakin meningkatnya minat dan kebutuhan masyarakat untuk melanjutkan belajar. Masyarakat sebagai konsumen lembaga pendidikan lebih kritis dan realitis dalam memilih lembaga pendidikan (sekolah). Lembaga pendidikan kini diharapkan lebih memfokuskan pada kebutuhan masyarakat sebagai pelanggannya dan lembaga pendidikan dituntut selalu melibatkan partisipasi masyarakat dalam pengelolaan

Maskur (2018:18): mengungkapkan "manajemen hubungan masyarakat adalah pengaturan tentang hubungan masyarakat baik internal maupun eksternal yang berkaitan dengan citra lembaga pendidikan, agar image dan kualitas tetap mendapat perhatian masyarakat bahkan mengalami perubahan dan pengembangan. Hal tersebut dimulai dari perencanaan guna pembentukan program, pelaksanaan dan evaluasi. Sedangkan menurut Cutlip dan Center dalam Zainal dan Muhibudin (2015 : 109): public relations atau humas dapat dibedakan pada fungsi manajemen melalui konsep kegiatan administrasi (operating concept of administration) dan fungsi staf khusus dalam pelayanan administrasi (specialized staff function serving administrator). Adapun dalam fungsi komunikasi, praktik public relations melaksanakan kegiatan komunikasi antara lembaga yang diwakilinya dan pihak publik sebagai sasarannya.

Pada prinsipnya, humas adalah kegiatan komunikasi yang terencana, dan memiliki fungsi internal dan eksternal dalam sebuah lembaga pendidikan. Dalam melaksanakan manajemen humas perlu adanya dukungan dari berbagai pihak agar proses pendidikan di sekolah dapat terlaksana dengan baik sehingga menghasilkan generasi penerus bangsa yang berkualitas. Hal itu terjadi karena keberhasilan pendidikan tidak hanya ditentukan dari lingkungan internal sekolah saja, tetapi juga 
ditentukan dari lingkungan eksternal sekolah yaitu dukungan dari keluarga, masyarakat, dan pemerintah.

Menurut Tampubolon dalam Sufiyyah (2011 : 85): menjelaskan bahwa pelayanan akademik memuat layanan pendidikan yang sangat besar. Pelayanan akademik merupakan pelayanan yang secara langsung berkaitan dengan peserta didik, sehingga lembaga pendidikan khususnya sekolah harus berusaha memahami serta memenuhi kebutuhan peserta didik. Lembaga pendidikan juga harus terus menerus meningkatkan kualitasnya dalam hal pelayanan pendidikan.

Berdasarkan hasil survei awal pada tanggal 16 Maret 2019, Sekolah Menengah Atas Negeri (SMAN) Darussholah Singojuruh adalah satusatunya sekolah menengah atas berstandart Negeri yang berada di kecamatan Singojuruh Kabupaten banyuwangi. Sekolah ini berdiri sejak tahun 2003. Dari tahun ke tahun SMAN Darussholah Singojuruh menunjukkan perkembangan yang yang cukup pesat. Hal ini ditunjukkan dari bertambahnya murid setiap tahun ajaran baru. Selain itu sekolah ini telah mengembangkan kurikulum berbasis agama yang bekerja sama dengan Pondok Pesantren Darussholah Singojuruh karena lokasinya berdampingan. Berikut adalah data nama-nama sekolah tingkat atas di kecamatan Singojuruh.

SMAN Darussholah Singojuruh menggunakan teknologi modern yaitu sms gateway dalam menyampaikan informasi-informasi yang ada kaitannya dengan guru, administrasi, siswa dan persekolahan. Selanjutnyan melakukan home visit atau kunjungan bersama guru BK dan wali kelas jika ada siswa yang tidak masuk sekolah. Dalam hal menuntut ilmu kualitas dan kuantitas pendidikan SMA Negeri Darussholah Singojuruh Kabupaten Banyuwangi tidak diragukan lagi. Oleh karena itu, saat ini SMAN Darussholah menjadi salah satu pilihan orang tua untuk menyekolahkan putra-putrinya.

Akan tetapi, bertambahnya siswa di SMAN Darussholah Singojuruh saat ini masih terdapat keluhan orangtua siswa terkait pelayanan yang ada di sekolah, yang disampaikan melalui media massa kepada WKS. Humas 
SMAN Darussholah Singojuruh. Hal ini menimbulkan citra kurang baik terhadap pelayanan di sekolah. Mengingat fungsi lembaga pendidikan adalah memberikan pelayanan pendidikan terhadap peserta didiknya, maka lembaga perlu terus meningkatkan kualitas pelayanan. Oleh karena itulah peneliti merasa penting untuk melakukan penelitian lebih lanjut terkait pengaruh manajemen hubungan masyarakat terhadap kualitas pelayanan akademik.

2. Rumusan Masalah

1) Bagaimanakah penerapan manajemen hubungan masyarakat SMAN Darussholah Singojuruh Banyuwangi?

2) Bagaimanakah kualitas pelayanan akademik SMAN Darussholah Singojuruh Banyuwangi?

3) Adakah pengaruh manajemen hubungan masyarakat terhadap kualitas pelayanan akademik SMAN Darussholah Singojuruh Banyuwangi?

3. Tujuan Penelitian

1) Untuk mengetahui penerapan manajemen hubungan masyarakat SMAN Darussholah Singojuruh Banyuwangi.

2) Untuk mengetahui kualitas pelayanan akademik SMAN Darussholah Singojuruh Banyuwangi.

3) Untuk mengetahui pengaruh manajemen hubungan masyarakat terhadap kualitas pelayanan akademik SMAN Darussholah Singojuruh Banyuwangi.

4. Manfaat Penelitian

1) Manfaat Teoritis

Untuk menambah pengetahuan tentang pengaruh manajemen hubungan masyarakat terhadap kualitas pelayanan akademik SMAN Darussholah Singojuruh.

2) Manfaat Praktis

a) Menambah pengetahuan dan pengalaman bagi peneliti yang khususnya berkenaan dengan masalah pengelolaan Manajemen Humas 
b) Sebagai salah satu syarat untuk memperoleh gelar sarjana pendidikan Islam

c) Sebagai bahan masukan bagi pengelola manajemen humas SMAN Darussholah Singojuruh untuk mengembangkan pengelolaan manajemen hubungan masyarakat.

d) Sebagai bahan referensi atau pedoman bagi peneliti selanjutnya yang akan meneliti hal-hal yang relevan dengan tema ini

\section{B. Landasan Teori}

1. Landasan Teori Tentang Manajemen Hubungan Masyarakat

a) Pengertian Manajemen Hubungan Masyarakat

Manajemen hubungan masyarakat (humas) adalah proses penelitian, pelaksanaan, perencanaan, dan pengevaluasian suatu kegiatan komunikasi yang didukung oleh organisasi. Humas merupakan terjemahan bebas dari istilah Public Relation atau bentuk komunikasi yang terselenggara antara organisasi yang bersangkutan dengan siapa saja yang berkepentingan dengannya.

Public relations atau yang biasa disebut humas mempunyai dua pengertian. Pertama, humas dalam arti sebagai teknik komunikasi atau technique of communication. Kedua, humas sebagai metode komunikasi atau method of ommunication. (Abdurrahman dalam Zainal dan Muhibudin, 2015 : 19).

Sebuah Hadits Rasulullah SAW. menggambarkan bahwa hubungan antar sesama muslim bagaikan suatu bangunan yang satu komponen dengan komponen yang lainnya saling memperkokoh, dalam sabdanya yang berbunyi:

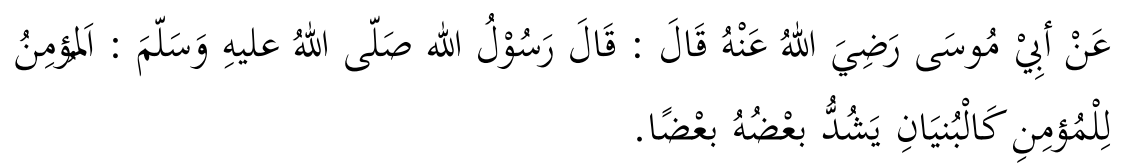

Artinya: Dari Abi Musa r.a. Rasulullah SAW. Bersabda: "Hubungan orang mu'min dengan mu'min yang lain bagaikan bangunan yang saling memperkokoh/menguatkan satu sama lain."

(H. R. Bukhori).

Pengaruh Manajemen Hubungan Masyarakat Terhadap Kualitas Pelayanan Akademik SMAN Darussholah Singojuruh Banyuwangi

Siti Aimah, Ulfa Dwi Yanti 
Islam seperti sebuah bangunan yang saling melengkapi dan mneguatkan. Atas dasar itu maka setiap individu menjadi salah satu bagian dari yang lainnya. Manusia menjadi kuat karena kesempurnaan anggota-anggota badannya. Setiap manusia memerlukan hubungan yang baik dalam hidupnya. Sebagai makhluk sosial manusia tidak bisa hidup sendiri, karena itu manusia saling menjalin komunikasi yang baik antar sesame. Baik itu dari keluarga, saudara, kerabat dan orang lain yang masih ada hubungannya.

b) Fungsi Manajemen Humas

Pada dasarnya fungsi manajemen tidak jauh berbeda dengan fungsi-fungsi manajemen secara umum. Fungi manajemen ini berkaitan dengan tujuan manajemen humas, dimana tujuan itu adalah suatu hasil akhir atau segala sesuatu yang akan dicapai. Untuk itu perlu adanya fungsi manajemen humas yang diantaranya: perencanaan, pengorganisasian, penggerakan, dan evaluasi.

c) Tujuan dan Fungsi Humas

Tujuan utama Public Relation sendiri adalah menciptakan, mempertahankan, dan melindungi reputasi organisasi/perusahaan, menampilkan citra-citra yang mendukung.

Menurut Nasution (2006 : 40) dalam Maskur (2017 : 29): menyatakan bahwa humas sekolah mempunyai tujuan untuk mengembangkan pemahaman kepada masyarakat tentang maksud dan sasaran sekolah, memberikan penilaian program kepada masyarakat untuk memenuhi kebutuhan sekolah, menjalin dan meningkatkan hubungan harmonis antara orang tua siswa dengan guru-guru dalam memenuhi kebutuhan anak didik.

2. Landasan Teori Kualitas Pelayanan Akademik

a) Pengertian Kualitas Pelayanan Akademik

Menurut Kamus Besar Bahasa Indonesia kualitas adalah baik buruknya sesuatu. Secara umum kualitas atau mutu adalah gambaran 
dan karakteristik menyeluruh dari barang atau jasa yang menunjukkan kemampuan dalam memuaskan yang diharapkan atau tersurat (Depdiknas, $2002: 7$ ).

Menurut Lupiyoadi ( 2014 : 63): kualitas adalah perpaduan antara sifat dan karakteristik yang menentukan sejauh mana keluaran dapat memenuhi persyaratan kebutuhan pelanggan, jadi pelanggan yang menentukan dan menilai sampai seberapa jauh sifat dan karakteristik tersebut memnuhi kebutuhannya.

b) Karakteristik Kualitas Pelayanan

Ponjtorini, dkk (2005 : 40): menyebutkan karakteristik jasa pendidikan meliputi: Intangibility, Inseparability, Variability, dan Perishability.

1) tidak terwujud (Intangibility)

Jasa tidak berwujud seperti produk fisik, yang menyebabkan pengguna jasa pendidikan tidak dapat melihat, mencium, mendengar, dan merasakan hasilnya sebelum mereka mengkonsumsinya (menjadi susbsistem lembaga pendidikan).

2) tidak terpisahkan (Inseparability)

Jasa pendidikan tidak dapat dipisahkan dari sumbernya, yaitu lembaga pendidikan yang menyediakan jasa tersebut. Artinya, jasa pendidikan dihasilkan dan dikonsumsi secara serempak (simultan) dalam waktu yang sama. Jika peserta didik membeli jasa maka akan berhadapan langsung dengan penyedia jasa pendidikan.

3) berubah-ubah (Variability atau Heterogeneit)

Jasa pendidikan yang diberikan seringkali berubah-ubah. Hal ini akan sangat tergantung kepada siapa yang menyajikannya, serta di mana disajikan jasa pendidikan tersebut.

4) tidak tahan lama (Perishability)

Jasa pendidikan tidak dapat disimpan dalam jangka waktu tertentu atau jasa pendidikan tersebut mudah musnah sehingga tidak dapat dijual pada waktu mendatang 
Berdasarkan beberapa karakteristik jasa pendidikan yang telah dikemukakan di atas, maka dapat disimpulkan bahwa pelayanan pendidikan yang ditawarkan lembaga pendidikan sebagai produknya memiliki sifat tidak terwujud, tidak dapat disimpan, dapat berubahubah tergantung yang menyajikan, dan membutuhkan keterlibatan siswa sebagai pelanggan dalam proses penyampaiannya.

c) Dimensi Kualitas Pelayanan Akademik

Untuk mengetahui sebuah pelayanan jasa khususnya jasa pendidikan yang berkualitas perlu adanya unsur-unsur pendukung sebagai bahan acuan.

Parasurahman dalam Ponjtorini, dkk (2005 : 42): menyebutkan lima dimensi kualitas jasa pelayanan, dimana jasa pendidikan merupakan bentuk jasa yang melibatkan tingkat interaksi yang tinggi antara penyedia jasa pendidikan (lembaga pendidikan) dan pengguna jasa pendidikan (siswa). Dimensi kualitas jasa pendidikan tersebut yaitu:

1) bukti fisik (Tangible)

Yaitu meliputi fasilitas fisik, perlengkapan, karyawan/staf pengajar, dan sarana komunikasi. Misalnya: fasilitas pembelajaran (gedung), fasilitas perpustakaan, media pembelajaran, fasilitas olahraga, serta busana staf administrasi maupun staf pengajar.

2) keandalan (Reliability)

Yaitu kemampuan memberikan pelayanan yang dijanjikan dengan segera atau cepat, akurat, dan memuaskan. Misalnya: mata pelajaran yang sesuai dengan kebutuhan peserta didik, jadwal pembelajaran, proses pembelajaran yang efektif, penilaian yang objektif, bimbingan dan penyuluhan, serta aktivitas lain yang semuanya untuk memperlancar proses pembelajaran peserta didik.

3) daya tanggap (Responsiveness)

Yaitu kemauan para staf untuk membantu para peserta didik dan memberikan pelayanan cepat dan tanggap. Misalnya: guru 
pembimbing mudah ditemui untuk konsultasi, prosedur administrasi lembaga pendidikan menjadi lebih sederhana.

4) jaminan (Assurance)

Yaitu mencakup pengetahuan, kompetensi, kesopanan, respek terhadap peserta didik, dan memiliki sifat dapat dipercaya. Misalnya: seluruh staf administrasi, staf pengajar, maupun pejabat structural harus benar-benar kompeten dibidangnya sehingga reputasi lembaga pendidikan positif di mata masyarakat.

5) empati (Empathy)

Yaitu kemudahan dalam melakukan hubungan, komunikasi dengan baik, perhatian pribadi, dan memahami kebutuhan peserta didiknya. Mislnya: staf pengajar mengenal siswanya yang mengikuti proses pembelajaran, guru bisa benar-benar berperan sesuai fungsinya, memberikan kemudahan dalam pelayanan, keramahan, dan kemampuan memahami kebutuhan siswanya.

3. Kajian Terdahulu

1) Kajian terdahulu oleh Afifatun Mudawamah (2009) dengan judul "Pengaruh Manajemen Hubungan Masyarakat Terhadap Peningkatan Kepuasan Layanan Akademik, di SMP Muhammadiyah 12 Lamongan". Penelitian ini bersifat deskriptif dengan pendekatan penelitian kuantitatif. Metode yang digunakan dalam penelitian ini diantaranya: observasi, wawancara, dokumentasi, dan angket. Untuk menghitung validitas data menggunakan teknik korelasi product moment. Dari hasil perhitungan diperoleh indeks korelasi rxy $=0,479$ dan tercantum pada nilai "r" product moment berkisar antara 0,40 0,70. Kesimpulan dari penelitiannya adalah penerapan konsep manajemen humas di SMP Muhammadiyah Lamongan cukup efektif dan memberikan pengaruh positif bagi peningkatan layanan akademik di sekolah tersebut.

2) Kajian terdahulu oleh Dyah Ayu Fitriana (2016) dengan judul "Kinerja Hubungan Masyarakat (HUMAS) Di Sekolah Menengah Kejuruan 
Yudya Karya Magelang”. Penelitian deskriptif dengan pendekatan kualitatif. Metode pengumpulan data dengan wawancara, observasi, dan studi dokumentasi. Teknik analisis data menggunakan model interaktif. Hasil penelitian melalui penerapan kinerja humas berkesimpulan bahwa: (1) perencanaan meliputi: penentuan tujuan humas, fungsi humas, penetapan sumber daya manusia melalui seleksi, perancangan program kerja, sasaran kerja humas, standar pelaksanaan kinerja, alat dan sarana kerja, (2) pelaksanaan meliputi: kinerja humas terhadap program kerja humas, kinerja humas terhadap program kerja sekolah, (3) evaluasi kinerja humas yang dilakukan tim humas SMK Yudya Karya Magelang hasilnya ditemukan kendala-kendala selama pelaksanaan kerjanya serta upaya yang dilakukan oleh humas untuk meningkatkan kinerja humas di SMK Yudya Karya Magelang agar dalam pelaksanaan kerja di periode selanjutnya berjalan lebih baik.

3) Kajian terdahulu oleh Nurhasanah (2014) dengan judul "Manajemen Hubungan Masyarakat Dalam Meningkatkan Partisipasi Masyarakat di SMK Muhammadiyah 1 Kepanjen. Penelitian ini merupakan penelitian dengan menggunakan pendekatan kualitatif dan jenis penelitian studi kasus. Teknik pengumpulan data dilakukam dengan wawancara mendalam, observasi partisipatif, dan studi dokumen. Hasil penelitian dari manajemen hubungan masyarakat yang diterapkan SMK Muhammadiyah 1 Kepanjen melalui tiga kegiatan. Pertama, kegiatan perencanaan diantaranya menganalisis keadaan dan kebutuhan masyarakat, merancang program sekolah dan merencanakan biaya yang dihabiskan dalam proses merealisasikan kegiatan. Kedua, pelaksanaan yang dilakukan melalui beberapa kegiatan yaitu: pelaksanaan promosi, kegiatan belajar mengajar, dan kelanjutan karir output yang dihasilkan. Ketiga, kegiatan evaluasi melalui rapat triwulan dan rapat disetiap akhir kegiatan. 


\section{Metode Penelitian}

Jenis penelitian ini menggunakan jenis penelitian deskriptif dengan metode kuantitatif. Populasi yang penulis gunakan dalam penelitian ini adalah guru dan karyawan SMAN Darussholah singojuruh Banyuwangi tahun pembelajaran 2018/2019 yang berjumlah 86 orang. Karena jumlah subjek kurang dari 100, penulis mengambil keseluruhan subjek yang diteliti yang berjumlah 86 orang sehingga penelitian ini disebut penelitian populasi. Untuk mengukur kevalidan sebuah instumen, penelitian ini menggunakan rumus korelasi product moment sedangkan Uji reliabilitas pada penelitian ini dengan rumus Alpha Cronbach“. Pengumpulan data dalam penelitian ini menggunakan metode observasi, angket, dan dokumentasi. Untuk teknik analisis data menggunakan analisis regresi linier sederhana.

\section{Hasil Penelitian}

1. Uji Validitas

Uji validitas merupakan cara untuk menguji apakah instrumen yang digunakan dapat mengukur seharusnya diukur atau tidak. Dalam penelitian ini uji validitas dilakukan dengan membandingkan $\mathrm{r}$ hitung dengan $r$ tabel. Apabila $r$ hitung lebih besar dari $r$ tabel, maka perbedaan yang ada adalah signifikan, sehingga instrumen bisa dinyatakan valid. Tingkat signifikansi adalah 0,05 atau 5\%. Hasil uji validitas dengan menggunakan SPSS versi 25 disajikan pada tabel berikut.

Tabel 1

Hasil Uji Validitas Variabel (X) Manajemen Hubungan Masyarakat

\begin{tabular}{|c|c|c|c|c|}
\hline No. & Item Pertanyaan & $\begin{array}{c}\text { Corrected Item- } \\
\text { Total Correlation }\end{array}$ & r tabel 5\% & Kriteria \\
\hline 1 & $\mathrm{X} .1$ & 0,433 & $>0,212$ & Valid \\
\hline 2 & $\mathrm{X} .2$ & 0,417 & $>0,212$ & Valid \\
\hline 3 & $\mathrm{X} .3$ & 0,402 & $>0,212$ & Valid \\
\hline 4 & $\mathrm{X} .4$ & 0,477 & $>0,212$ & Valid \\
\hline 5 & $\mathrm{X} .5$ & 0,395 & $>0,212$ & Valid \\
\hline 6 & $\mathrm{X} .6$ & 0,614 & $>0,212$ & Valid \\
\hline 7 & $\mathrm{X} .7$ & 0,322 & $>0,212$ & Valid \\
\hline 8 & $\mathrm{X} .8$ & 0,402 & $>0,212$ & Valid \\
\hline 9 & $\mathrm{X} .9$ & 0,584 & $>0,212$ & Valid \\
\hline 10 & $\mathrm{X} .10$ & 0,302 & $>0,212$ & Valid \\
\hline
\end{tabular}

Pengaruh Manajemen Hubungan Masyarakat Terhadap Kualitas Pelayanan Akademik SMAN Darussholah Singojuruh Banyuwangi 


\begin{tabular}{|l|l|l|l|l|}
\hline 11 & X.11 & 0,327 & $>0,212$ & Valid \\
\hline 12 & X.12 & 0,499 & $>0,212$ & Valid \\
\hline 13 & X.13 & 0,488 & $>0,212$ & Valid \\
\hline 14 & X.14 & 0,504 & $>0,212$ & Valid \\
\hline 15 & X.15 & 0,511 & $>0,212$ & Valid \\
\hline 16 & X.16 & 0,483 & $>0,212$ & Valid \\
\hline 17 & X.17 & 0,505 & $>0,212$ & Valid \\
\hline 18 & X.18 & 0,519 & $>0,212$ & Valid \\
\hline 19 & X.19 & 0,440 & $>0,212$ & Valid \\
\hline 20 & X.20 & 0,569 & $>0,212$ & Valid \\
\hline
\end{tabular}

Sumber: Hasil Olah Data Penelitian, Juli 2019.

Berdasarkan data pada tabel 1 di atas, diketahui bahwa semua pengujian terhadap instrumen variabel $X$, nilai $r$ hitung lebih besar dari $r$ tabel maka pertanyaan tersebut valid. Diketahui bahwa $r$ tabel dari taraf signifikansi 0,05 dengan dk $86-2=84$ adalah 0,212. Dengan demikian semua butir pertanyaan dalam kuesioner tersebut dapat dinyatakan valid dan dapat digunakan untuk mengumpulkan data yang diperlukan.

Tabel 2

Hasil Uji Validitas (Y)

Kualitas Pelayanan Akademik

\begin{tabular}{|c|c|c|c|c|}
\hline No. & Item Pertanyaan & $\begin{array}{l}\text { Corrected Item- } \\
\text { Total Correlation }\end{array}$ & r tabel 5\% & Kriteria \\
\hline 1 & Y.1 & 0,542 & $>0,212$ & Valid \\
\hline 2 & Y.2 & 0,658 & $>0,212$ & Valid \\
\hline 3 & Y.3 & 0,553 & $>0,212$ & Valid \\
\hline 4 & Y.4 & 0,730 & $>0,212$ & Valid \\
\hline 5 & Y.5 & 0,417 & $>0,212$ & Valid \\
\hline 6 & Y.6 & 0,546 & $>0,212$ & Valid \\
\hline 7 & Y.7 & 0,655 & $>0,212$ & Valid \\
\hline 8 & Y.8 & 0,624 & $>0,212$ & Valid \\
\hline 9 & Y.9 & 0,583 & $>0,212$ & Valid \\
\hline 10 & Y.10 & 0,676 & $>0,212$ & Valid \\
\hline 11 & Y.11 & 0,681 & $>0,212$ & Valid \\
\hline 12 & Y.12 & 0,396 & $>0,212$ & Valid \\
\hline 13 & Y.13 & 0,601 & $>0,212$ & Valid \\
\hline 14 & Y.14 & 0,470 & $>0,212$ & Valid \\
\hline 15 & Y.15 & 0,261 & $>0,212$ & Valid \\
\hline 16 & Y.16 & 0,603 & $>0,212$ & Valid \\
\hline 17 & Y.17 & 0,717 & $>0,212$ & Valid \\
\hline 18 & Y.18 & 0,707 & $>0,212$ & Valid \\
\hline 19 & Y.19 & 0,699 & $>0,212$ & Valid \\
\hline 20 & Y.20 & 0,604 & $>0,212$ & Valid \\
\hline
\end{tabular}

Pengaruh Manajemen Hubungan Masyarakat Terhadap Kualitas Pelayanan Akademik SMAN Darussholah Singojuruh Banyuwangi

Siti Aimah, Ulfa Dwi Yanti 
Sumber: Hasil Olah Data Penelitian, Juli 2019.

Berdasarkan data pada tabel 2 di atas, diketahui bahwa semua pengujian terhadap instrumen variabel $X$, nilai $r$ hitung lebih besar dari $r$ tabel maka pertanyaan tersebut valid. Diketahui bahwa $r$ tabel dari taraf signifikansi 0,05 dengan dk $86-2=84$ adalah 0,212. Dengan demikian semua butir pertanyaan dalam kuesioner tersebut dapat dinyatakan valid dan dapat digunakan untuk mengumpulkan data yang diperlukan.

2. Uji Reliabilitas

Sebuah instrumen dapat dikatakan reliabel apabila memenuhi persyaratan nilai Cronbach's Alpha lebih besar dari 0,60. Pengambilan keputusan untuk uji reliabilitas data menurut Perry Roy Hilton and Charlotte Brownlow, 2004:364 dalam Suryana (2015 : 239) yaitu:

a. Jika alpha $>0,90$ maka reliabilitas sempurna

b. Jika alpha antara $0,70-0,90$ maka reliabilitas tinggi

c. Jika alpha antara 0,50-0,70 maka reliabilitas moderat

d. Jika alpha $<0,50$ maka reliabilitas rendah

Berikut ini hasil uji reliabilitas variabel $\mathrm{X}$ dan variabel $\mathrm{Y}$ dengan menggunkan SPSS versi 25.

Tabel 3

Hasil Uji Reliabilitas Data

\begin{tabular}{|c|c|c|}
\hline Variabel & $\begin{array}{c}\text { Cronbach's } \\
\text { Alpha }\end{array}$ & Kriteria \\
\hline Manajemen Humas & .796 & Tinggi \\
\hline Kualitas Pelayanan Akademik & .743 & Tinggi \\
\hline
\end{tabular}

Sumber: Hasil Olah Data Penelitian, Juli 2019.

Berdasarkan hasil analisis pada tabel 3 menunjukkan bahwa nilai Cronbach's Alpha variabel X (Manajemen Humas) dan variabel Y (Kualitas Pelayanan Akademik) ada pada kriteria tinggi. Dengan demikian dapat disimpulkan bahwa semua alat ukur yang digunakan dalam penelitian ini adalah reliabel. 
3. Analisis Data dan Uji Hipotesis

a. Analisis Data

Sebagaimana disampaikan pada bagian sebelumnya, bahwa penelitian ini menggunakan satu variabel bebas atau satu prediktor. Oleh karena itu analisis data yang digunakan dalam penelitian ini adalah regresi linier sederhana. Kegunaan analisis regresi linier sederhana adalah untuk mengukur besarnya pengaruh variabel bebas terhadap variabel terikat. Sebelum melakukan perhitungan pada rumus regresi linier sederhana, terlebih dahulu mengetahui jumlah skor $\mathrm{X}$ dan Y, kuadrat dari skor X dan Y, dan perkalian dari jumlah skor X dan Y yang disajikan pada tabel berikut:

Hasil uji regesi linier sederhana dibuktikan dengan hasil dari perhitungan dengan SPSS sebagai berikut:

Tabel 4.

Hasil Uji Regresi Linier Sederhana

Coefficients $^{\mathrm{a}}$

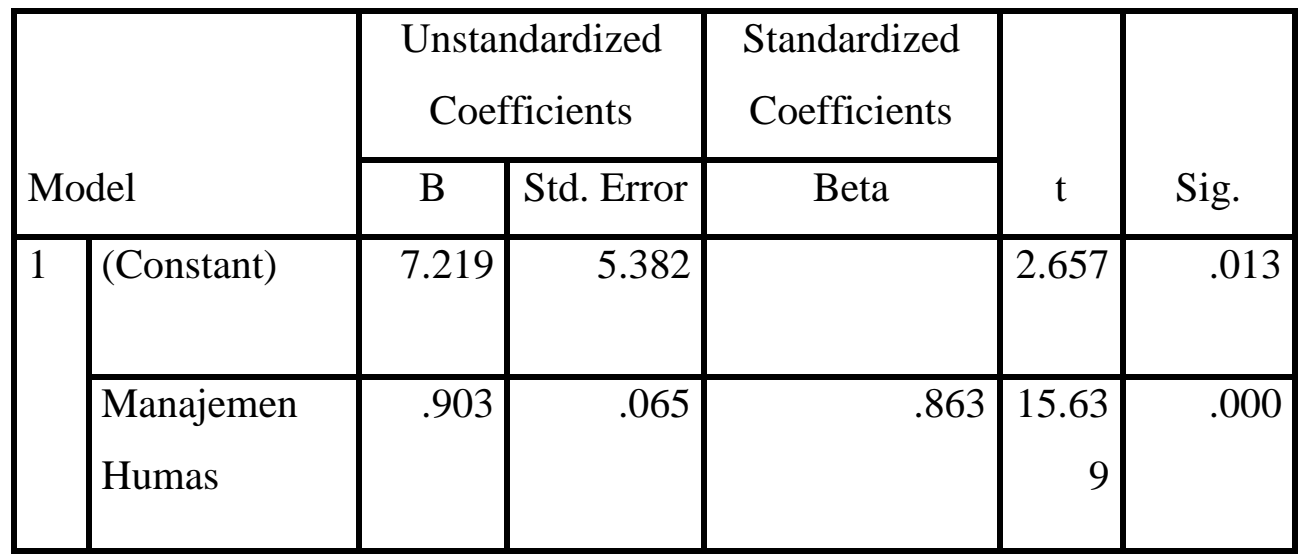

a. Dependent Variable: Kualitas Pelayanan

Sumber: Output IBM SPSS V.25

Berdasarkan tabel Coefficients Konstanta $(\alpha)$ sebesar 7.219, menyatakan bahwa jika tidak ada manajemen hubungan masyarakat, maka kualitas pelayanan akademik adalah 7.219. Koefisien regresi (b) sebesar 0,903, menyatakan bahwa setiap penambahan (karena nilai koefisien regresi bernilai positif (+)) satu skor manajemen hubungam masyarakat akan meningkatkan kualitas pelayanan akademik sebesar 0,903 .

Pengaruh Manajemen Hubungan Masyarakat Terhadap Kualitas Pelayanan Akademik SMAN Darussholah Singojuruh Banyuwangi

Siti Aimah, Ulfa Dwi Yanti 
b. Uji Hipotesis

1. Uji T

Uji T digunakan untuk mengetahui apakah variabel manajemen hubungan masyarakat $(\mathrm{X})$ dan variabel kualitas pelayanan akademik (Y) signifikan atau tidak. Kesimpulan dari uji $\mathrm{T}$ diperoleh setelah membandingkan thitung dan t tabel dengan taraf signifikansi 0,05 atau 5\%. Kriteria pengambilan keputusannya adalah:

a) Apabila $\mathrm{t}$ hitung > t tabel, maka Ho ditolak dan Ha diterima, yang artinya variabel bebas secara parsial memiliki pengaruh nyata dan signifikan terhadap variabel terikat.

b) Apabila t hitung < t tabel, maka Ho diterima dan Ha ditolak, yang artinya variabel bebas secara parsial tidak memiliki pengaruh nyata dan signifikan terhadap variabel terikat.

Hasil analisis uji t dalam penelitian ini disajikan dalam tabel output SPSS sebagai berikut:

Tabel 5

Uji T hitung

Coefficients $^{\mathrm{a}}$

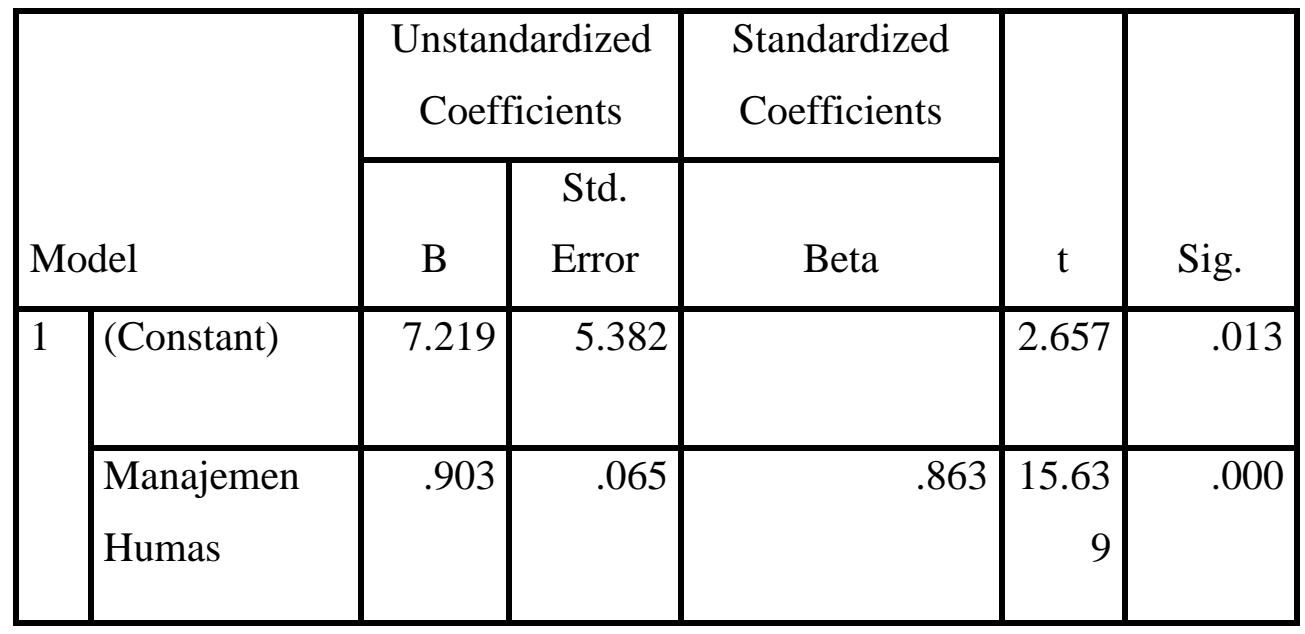

a. Dependent Variable: Kualitas Pelayanan

Sumber: Output IBM SPSS V.25

Berdasarkan tabel hasil uji $\mathrm{t}$ di atas, dapat disimpulkan bahwa variabel manajemen hubungan masyarakat $(\mathrm{X}) \mathrm{t}$ hitung sebesar 15,639 dibandingkan dengan $\mathrm{t}$ tabel dengan derjat kebebasan ( $\mathrm{dk}$ ) atau degree of freedom (df), $\mathrm{n}-2=86-2=84$ dengan taraf signifikansi $5 \%$ dan 
pengujiannya dilakukan dengan menggunakan uji dua arah, maka t tabel diperoleh 1,988 .

Dari hasil uji $\mathrm{t}$ di atas menghasilkan hasil uji $\mathrm{t}$ hitung $>\mathrm{t}$ tabel, yaitu 15,639>1,988, maka Ha diterima dan. Hal tersebut dapat diartikan bahwa variabel manajemen hubungan masyarakat SMAN Darussholah Singojuruh Banyuwangi tahun pembelajaran 2018/2019 tergolong baik. Sedangkan pada hasil uji $\mathrm{t}$ diperoleh hasil hitung variabel kualitas pelayanan akademik sebesar 2,657 dibandingkan dengan t tabel pada derajat kebebasan (df) $86-2=84$, dan taraf signifikansi 5\% adalah 1,988. Hasil interpretasi $\mathrm{t}$ hitung $>\mathrm{t}$ tabel, maka Ha diterima. Jadi, hasil penellitian ini menunjukkan bahwa kualitas pelayanan akademik SMAN Darussholah Singojuruh tergolong baik.

2. Uji F

Uji F atau uji koefisien regresi digunakan untuk mengetahui apakah variabel manajemen hubungan masyarakat $(\mathrm{X})$ dan varibel kualitas pelayanan akademik (Y) secara signifikan atau tidak. Kesimpulan dari uji $\mathrm{F}$ ini diperoleh dengan cara membandingkan $\mathrm{F}$ hitung dan $\mathrm{F}$ tabel dengan taraf signifikansi 0,05 atau 5\%. Kriteria pengambilan keputusannya adalah:

a) Apabila F hitung > F tabel, maka Ho ditolak dan Ha diterima, yang artinya variabel bebas secara simultan memiliki pengaruh yang signifikan terhadap variabel terikat

b) Apabila F hitung < F tabel, maka Ho diterima dan Ha ditolak, yang artinya variabel bebas tidak memiliki pengaruh yang signifikan terhadap variabel terikat.

Hasil analisis uji $\mathrm{F}$ dalam penelitian ini disajikan dalam tabel berikut ini: 


\section{Tabel 6}

\section{Uji F hitung}

ANOVAa

\begin{tabular}{|l|l|c|r|r|r|r|}
\hline \multicolumn{2}{|c|}{ Model } & $\begin{array}{c}\text { Sum of } \\
\text { Squares }\end{array}$ & Df & $\begin{array}{c}\text { Mean } \\
\text { Square }\end{array}$ & F & Sig. \\
\hline 1 & Regressio & 3977.328 & 1 & 3977.328 & 247.754 & $.000^{\mathrm{b}}$ \\
& $\mathrm{n}$ & & & & & \\
& Residual & 1348.497 & 84 & 16.054 & & \\
& Total & 5325.826 & 85 & & & \\
\hline
\end{tabular}

a. Dependent Variable: Kualitas Pelayanan Akademik

b. Predictors: (Constant), Manajemen Humas

Berdasarkan hasil yang tersaji pada tabel 4.15 di atas, diketahui bahwa F hitung sebesar 247.754 dibandingkan F tabel dengan (df) $86-2$ $=84$ dan taraf signifikansi 5\% yaitu 3,950 menghasilkan hasil uji $\mathrm{F}$ hitung > f tabel yaitu $247.754>3,950$, maka Ha diterima, yang berarti variabel bebas manajemen hubungan masyarakat $(\mathrm{X})$ secara simultan memiliki pengaruh signifikan terhadap variabel terikat kualitas pelayanan akademik (Y).

\section{E. Pembahasan}

1. Manajemen Humas

Pada bagian sebelumnya, telah diuraikan permasalahan pertama yang dipertanyakan pada penelitian ini yaitu bagaimana penerapan manejemen humas SMAN Darussholah Singojuruh tahun pembelajaran 2018/2019. Setelah melakukan analisis data, berdasarkan uji t diperoleh hasil hitung manajemen hubungan masyarakat (X) sebesar 15,639 dibandingkan $\mathrm{t}$ tabel dengan $\mathrm{n}=86-2$ dan taraf signifikansi $5 \%=1,988$. Dari data tersebut, jika diinterpretasikan dengan kriteria pengujian ialah hasil uji t hitung > t tabel, maka Ha diterima. Jadi hasil penelitian ini menunjukkan bahwa manajemen hubungan masyarakat SMAN 
Darussholah Singojuruh Banyuwangi tahun pembelajaran 2018/2019 tergolong baik.

2. Kualitas Pelayanan Akademik

Sesuai dengan apa yang diuraikan pada bagian sebelumnya bahwa permasalahan kedua yang dipertanyakan dalam penelitian ini adalah bagaimana kualitas pelayanan akademik SMAN Darussholah Singojuruh 2018/209, maka hasil penelitian ini menunjukkan bahwa pada uji $\mathrm{t}$ diperoleh hasil hitung variabel kualitas pelayanan akademik (Y) sebesar 2.657 dibandingkan $\mathrm{t}$ tabel dengan derajat kebebasan $(\mathrm{dk}) 86-2=84$ dan taraf signifikansi $5 \%$ sebesar 1,988. Hasilnya interpretasi t hitung $>\mathrm{t}$ tabel, maka Ha diterima. Jadi, hasil penelitian ini menunjukkan bahwa kualitas pelayanan akademik SMAN Darussholah Singojuruh tergolong baik.

3. Pengaruh Manajemen Humas Terhadap Kualitas Pelayanan Akademik SMAN Darussholah Singojuruh

Hasil dari pengujian regresi linier sederhana adalah untuk mengetahui seberapa besar pengaruh variabel bebas manajemen hubungan masyarakat $(\mathrm{X})$ terhadap variabel terikat kualitas pelayanan akademik (Y). Dari hasil uji regresi linier sederhana, dihasilkan bahwa pengaruh manajemen hubungan masyarakat sebesar $74,4 \%$ sisanya $25,6 \%$ dipengaruhi oleh variabel lain yang tidak diteliti.

\section{F. Kesimpulan}

Berdasarkan hasil pembahasan, analisis data, diskusi hasil penelitian, dan interpretasi, serta data di lapangan, maka dapat diambil kesimpulan sebagai berikut:

1. Berdasarkan uji $\mathrm{t}$ diperoleh hasil hitung variabel manajemen hubungan masyarakat $(\mathrm{X})$ sebesar 15,639 dibandingkan $\mathrm{t}$ tabel dengan $\mathrm{n}=86-2$ dan taraf signifikansi 5\%=1,988. Dari data tersebut, jika diinterpretasikan dengan kriteria pengujian ialah hasil uji t hitung > t tabel, maka $\mathrm{Ha}$ diterima. Jadi hasil penelitian ini menunjukkan bahwa manajemen hubungan masyarakat SMAN Darussholah Singojuruh Banyuwangi tahun pembelajaran 2018/2019 tergolong baik. 
2. Berdasarkan uji t diperoleh hasil hitung variabel kualitas pelayanan akademik (Y) sebesar 2.657 dibandingkan $\mathrm{t}$ tabel dengan derajat kebebasan (dk) $86-2=84$ dan taraf signifikansi 5\% sebesar 1,988. Hasilnya interpretasi $\mathrm{t}$ hitung > t tabel, maka Ha diterima. Jadi, hasil penelitian ini menunjukkan bahwa kualitas pelayanan akademik SMAN Darussholah Singojuruh tergolong baik.

3. Berdasarkan penghitungan yang dilakukan dengan menggunakan rumus regresi sederhana dengan prosentase nilai $R$ Square sebesar 0,744 yang berarti bahwa manajemen hubungan masyarakat (X) mempunyai pengaruh yang kuat terhadap kualitas pelayanan akademik (Y) sebesar 74,4\% sisanya 25,6\% dipengaruhi oleh variabel lain yang tidak diteliti.

\section{G. Daftar Pustaka}

Arikunto, Suharsimi. Prosedur Penelitian Suatu Pendekatan Praktik. Jakarta: Rineka Cipta, 2010.

As'ari, Ruli. Pengetahuan dan Sikap Masyarakat dalam Melestarikan Lingkungan.

Jurnal GeoEco, Vol. 4, No. 1, 2018.

Hidayat, Rahmat dan Candra Wijaya. 2017. Ayat-ayat Al-Quran. Tentang Manajemen Pendidikan Islam. Medan: LPPI

Iriantara, Yosal. 2013. Manajemen Humas Sekolah. Bandung: Simbiosa Rekatama Media

Lupiyoadi, Rambat. 2013. Manajemen Pemasaran Jasa. Jakarta: Salemba Empat.

Mahmud, Hilal. 2015. Administrasi Pendidikan (Menuju Sekolah Efektif). Makassar: Aksara Timur

Maskur. 2018. Manajemen Humas Pendidikan Islam (Teori dan Aplikasi). Yogyakarta: Deepublish

Mukarom, Zainal dan Muhibudin Laksana. 2015. Manajemen Public Relation. Bandung: CV Pustaka Setia

Mulyasa, 2005. Manajemen Berbasis Sekolah (Konsep Strategi dan Implementasi). Bandung: Remaja Rosda Karya, 46 
Musfah, Jejen. 2015. Manajemen Pendidikan (Teori, Kebijakan, dan Praktik). Jakarta: KENCANA

Mustapa, Zainuddin dan Maryadi. 2018. Kepemimpinan pelayanan. Makassar: Celebes Media Perkasa

Nurtjahjani, Fullchis. 2018. Public Relations (Citra dan Praktek). Malang: POLINEMA PRESS

Rochmah, Siti. 2013. Responsivitas Pelayanan. Malang: Universitas Brawijaya (UB Press)

Sarmanu. 2017. Dasar Metode Penelitian (Kuantitatif, Kualitatif, \& Statistika). Surabaya: Airlangga University Press

Sugiyono. 2015. Metode Penelitian Pendidikan. Bandung: Alfabeta

Sugiyono. 2016. Metode Penelitian Pendidikan (Pendekatan Kuantitatif, Kualitatif, dan $R \& D)$. Bandung: Alfabeta

Tjiptono, Fandy dan Gregorius Chandra. 2011. Service, Quality \& Satisfaction. Yogyakarta: Andi

Yusuf, Muri. 2017. Metode Penelitian (Kuantitatif, Kualitatif, dan Penelitian Gabungan). Jakarta: KENCANA 